\title{
Positioning and change in a hospital ward
}

\author{
Kjærbeck, Susanne
}

Published in:

Journal of Organizational Change Management

DOI:

10.1108/JOCM-05-2016-0094

Publication date:

2017

Document Version

Peer reviewed version

Citation for published version (APA):

Kjærbeck, S. (2017). Positioning and change in a hospital ward. Journal of Organizational Change Management, 30(1), 43-53. https://doi.org/10.1108/JOCM-05-2016-0094

\section{General rights}

Copyright and moral rights for the publications made accessible in the public portal are retained by the authors and/or other copyright owners and it is a condition of accessing publications that users recognise and abide by the legal requirements associated with these rights.

- Users may download and print one copy of any publication from the public portal for the purpose of private study or research.

- You may not further distribute the material or use it for any profit-making activity or commercial gain.

- You may freely distribute the URL identifying the publication in the public portal.

\section{Take down policy}

If you believe that this document breaches copyright please contact rucforsk@kb.dk providing details, and we will remove access to the work immediately and investigate your claim. 


\title{
Positioning and change in a hospital ward
}

\author{
Susanne Kjærbeck \\ Dept. of Communication and Arts, \\ Roskilde University, DK
}

susannek@ruc.dk

\begin{abstract}
Purpose -This article focuses on communication about hygiene in a hospital ward and with the relevant infection control organization. The purpose is to examine the function of the hygiene coordinator as a key change agent and the communicative challenges and role conflicts implied in her practice. The author suggests strategies for improving communication on hygiene on ward level.
\end{abstract}

Design/methodology/approach - The empirical material consists of interviews and recordings of communicative events in relation to a breakout of dangerous bacteria in the ward. Change communication is used as a contextualizing frame of understanding, and positioning theory and analysis are applied to shed light upon the core challenges of communicating as a change agent when the coordinator's professional position and collegial relations do not support it.

Findings - It is shown how these challenges are connected to positional dilemmas regarding professional hierarchies and collegial relations. In order to have the hygiene coordinator gain authority and achieve empowerment in her function, additional documentation and training are needed, and communication efforts between the department management and the hygiene coordinator need strengthening. Furthermore, the hygiene area should be connected to the hospital's overarching purpose of saving lives.

Originality/value - These findings point to the importance of taking communication on the departmental level into consideration in relation to change strategies, and they highlight the centrality of strategic positioning practices in a work environment which is organized in professional groups and according to distributed responsibilities.

Keywords change communication, positioning, hygiene in hospitals, role conflict, empowerment Paper type Research paper 


\section{Introduction}

"Hospital infections know no boundaries, whereas boundaries play a major role in the functioning of a hospital ward” (From interview with hygiene coordinator)

In the Danish hospital world the 'burning platform' is that appr. 10\% of hospitalized patients get hospital infections they did not have in the first place (Braut and Holt, 2011). In order to reduce risk, the Danish Quality Assessment Programme (http://www.hpm.org/dk/a14/1.pdf) introduced the function of the hygiene coordinator which is predominantly performed by a nurse. The hygiene coordinator serves as a practical link between the central infection control organization and the ward, and as a local change agent with the task of supporting existing procedures and communicating and facilitating new procedures of hygiene in the ward. In order to reduce infection risk, the hygiene coordinator has become the key 'change agent' at ward level.

This article reports on an empirical research project undertaken in a major Danish hospital in 20122013 in collaboration with Associate Professor Helle Petersen, Roskilde University (for preliminary results, see Kjærbeck and Petersen, 2015). It focuses on communication about hygiene in a hospital ward, and especially on the strategic communication and positioning of the hygiene coordinator. The job of the hygiene coordinator is difficult, the main challenge being how to persuade local management and different professional groups in the ward, e.g. doctors, nurses, and assistants, to accept and adopt new and often cumbersome and time-consuming procedures. The undertaking of this task implies role conflicts and relational dilemmas and requires strategic management of positions and relations. The relational dilemmas appear in the form of problems of authority which derive, to some extent, from the fact that the function as change agent is performed by an employee, and not by a front-line or middle manager, as is usually the case in healthcare (Hewison, 2002, in Kelliher and Parry, 2015) and other organizations (Floyd and Wooldridge, 1997; Balogun, 2003). At the same time, having an employee as the central change agent has clear advantages, such as securing the detailed knowledge of the procedures 'on the ground' and cultural and linguistic competences when it comes to strategic communication with fellow nurses and aids.

\section{Method and study design}

The purpose of this study is 1 . To give insight into the challenges faced by the hygiene coordinator as a central change agent in the relevant organizational context, and 2. To point to strategies for improving communication on hygiene and ultimately the level of hygiene in the ward.

The study was undertaken in two hospital wards. One of them is under scrutiny on this occasion, and will function as a case study. This ward had recently experienced a breakout of the resistant bacteria Clostridium difficile which had spread between patients at the ward, although hospitalized in different rooms and unable to leave the rooms. Infections with Clostridium difficile present serious conditions for hospitalized people with poor immune systems.

When such breakouts of resistant types of bacteria occur, microbiologists and hygiene nurses from the infection control organization start a detailed investigation of the involved department and their hygiene and cleaning procedures. Following written and oral audits with descriptions of the place 
and recommendations as to how to avoid breakouts in the future, new cleaning procedures were introduced. This is where the hygiene coordinator comes into operation. Her most important task is to take care of the implementation of these recommendations at the ward - a task which needs to be developed into practical measures. In this process, the hygiene coordinator often consults the hygiene nurses as well as the chief nurse and possibly other coordinators. Ultimately, the change needs approval by the department management (chief nurse and chief physician) before it is communicated to the relevant staff at the department.

An explorative, qualitative approach was adopted in order to find out what kind of communicative challenges were at stake and grasp the complexity of the hygiene coordinator's function as a practical link between the infection control organization and the department, and between the department management and the staff.

The data consists of recorded departmental meetings where the hygiene nurses presented their audits and where the hygiene coordinator presented the involved change of cleaning procedures to staff as well as semi-structured interviews with local management, hygiene nurses from the infection control organization, hygiene coordinators, and aids. Furthermore, written information material elaborated by the hygiene coordinator was analyzed, and participant observation was undertaken in the hospital rooms and in a course for new hygiene coordinators. The empirical part of the study was collected in a major Danish hospital during a period of appr. six months.

This article presents excerpts from interviews with a hygiene coordinator, the chief physician, the chief nurse, and one of the hygiene nurses. Furthermore, we look into the communicative strategies used by the hygiene coordinator at a 'difficult' meeting where she had to 'sell' the new and cumbersome cleaning procedures to the staff. The meeting data offers a window into practical enactment of hygiene communication, whereas the interviews provide informants' interpreted accounts. In both data types, situational factors such as the presence and actions of the researcher as well as e.g. previous communication of research interests must be considered influential to the participant's/interviewee's contribution (Kvale, 2008; Gubrium and Holstein, 1995 and 2002; Hazel, 2015; Lucius-Hoehne and Deppermann, 2000; Kjærbeck, 2014). The transcribed data was analyzed from a content-oriented approach in order to answer the research questions, but with a view to the local context and communicative situation in which relevant statements were expressed.

\section{Change communication and organizational issues}

In order to determine the changes in focus, it is relevant to consider the descriptive categories of first-order and second-order changes. While first-order changes are considered necessary changes 'in order not to change' such as changes in work practices, second-order changes refer to radical structural changes of the organization (Zorn et al., 1999:11; Lewis, 2011). In our case, the practical changes regarding cleaning procedures, procedures for hand hygiene, and use of equipment can obviously be conceived of as first-order changes, whereas changes in the area of infection control like the introduction of the hygiene coordinator function in all hospital departments are quite significant to the organization, thus more like a second-order change. The changes, seemingly, fall between the categories; they are consequential to the organization and enactment of the staff's daily 
work practices, although they are not dramatic or threatening the existence of the organization in any way.

Many researchers consider change a basic feature of organizing (Weick and Quinn, 1999; Lewis, 2011; Tsoukas and Chia, 2002; Fenton and Langley, 2011). However, organizational change and change processes can be more or less planned (Lewis, 2011). In this case, the Danish Quality Assessment Programme paved the way for changes in the hygiene area, and the subsequent practical processes may be conceived of as strategic, purposeful changes.

The 'burning platform' (Kotter, 1995) with regard to hygiene is primarily caused by the hospital's external environment, i.e. the use of antibiotics in the pork production which has led to the development and spread of resistant bacteria (Kolmos, 2012; Dahllöf, 2014). Due to this situation, antibiotics have reduced or, in some cases, no effect, and therefore improvement of hygiene is increasingly a matter of life or death.

The process of change in organizations often follow the stages of diffusion theory, namely innovation, diffusion and adoption, and discontinuance (Rogers, 1983; Lewis, 2011), which can be used as a framework for analysis. Procedural changes in relation to hygiene can be conceived of as innovation, and it is the coordinator's task to communicate the new procedures and 'sell' these ideas and practices to involved staff and lay the ground for their adoption (see also Dutton et al., 2002 on the notion of 'issue selling').

The hygiene coordinator is an important change agent in the ward, but as implied in the title 'coordinator' she does not have management responsibility - she is authorized by the department management, certain tasks are so to speak delegated to her ad hoc, but the responsibility stays with the department management. This in-between status seemingly conflicts with the organizational context. Hospitals usually have a vertical organizational structure with many layers of management, and with most of the organization's staff working in very specific, narrow roles with low authority. The structure is designed to ensure that tasks are being done exactly and correctly (Feigenbaum, http://smallbusiness.chron.com/organizational-structure-hospitals-3811.html). This centralized design limits integration across functions and the ability to develop innovative, creative quality improvement processes and solutions at the level of the service line (Glickman et al., 2007).

In this vertical organizational structure, personnel are organized in three major professional divisions: the medical division, the nursing division, and other health professionals (Sultz and Young, 2010). The physicians constitute a powerful resource in hospitals, and they have a decisive influence on many change efforts. The hierarchy and existent patterns of influence are in many respects challenged by problems with hygiene which obviously go across professional groups and tasks. And the hygiene coordinator is faced with problems due to the necessity of working across professional groups and tasks.

Change communication is focused on the strategic endeavor of influencing staff's or other recipients' knowledge, attitudes and behavior, and researchers have emphasized dialogue as a means to obtain the necessary understanding and support of the change (Rogers, 1971; Anderson et al., 2004; Petersen, 2000; Gergen et al., 2004; Larkin and Larkin, 1994). As early as 1971 Rogers 
wrote: "if A's objective is to persuade B to form a favorable attitude toward the innovation, an interpersonal channel is more effective” (Rogers, 1971:24). The dialogue aspect is seemingly another reason for appointing a nurse hygiene coordinator - since she is placed in the ward, she is able to conduct dialogue on a daily basis and has the necessary local knowledge to be able to ‘translate' suggested changes into practical procedures in the ward.

Zorn et al. pose the rhetorical question: 'Who can be against dialogue? Or quality? Yet on the specific meanings of these terms as applied to work processes, products, and services, we may have lots of different ideas' (1999:10). These researchers present a more critical perspective to organizational change and change communication: Change becomes the overarching value under which are placed more specific programs focused on costumer service, organizational excellence/quality, and teamwork' (Zorn et al., 2000:518). This development also applies to the public sector in Western countries. Many of the key challenges and pressures in the public sector reflect the situation in the private sector, i.e. the need to do more with fewer resources, the need for increased flexibility, increased controls and work intensification (Omari and Paul, 2015; Kelliher and Parry, 2015). These New Public Management-driven changes are felt to be stressful, especially by managers concerned with implementation (Kelliher and Parry, 2015; Hildebrandt, 2014).

Hildebrandt (2014) calls for a showdown with the so-called 'documentation tyranny' caused by the NPM paradigm and the ideas of control, documentation, and centralization which cause stress and reduced quality (see also Hildebrandt and Brandi, 2010).

The Danish health sector is highly influenced by change management and the NPM paradigm, and the data reveals this condition. Especially the department management experiences the pressure of the focus on efficiency and measurement, evaluation, and bureaucracy. And in the initiative of the Danish Quality Model, improvement of hygiene is linked to the overall goal of 'quality', which paved the way for introducing the function of the hygiene coordinator.

\section{Positioning theory}

In the hospital world, professional hierarchies play a major role, and therefore it is necessary to take positioning issues into consideration when dealing with communicative challenges. The data shows that staff, in their daily work life, orient very much to the rights and duties attached to professional functions and positions in the hierarchy. Communication about hygiene and the practical implementation of hygiene procedures take place in this context. As a consequence, the relational side of practical communication comes to the forefront in this study, and positioning theory (Harré and Van Langenhove, 1999; Harré, 2012; James, 2010 and 2014) is employed in order to shed light upon the relevant positions and their strategic use.

Positioning theory and analysis focus on how relations and identities (the so-called positions) and their attached rights and duties set the basic framework for practical communication, how positions are invoked and negotiated through language use (Davies and Harré, 1990; Harré and Van Langenhove, 1999; Moghaddam and Harré, 2003; Bamberg, 2008; Deppermann, 2014; Day and Kjaerbeck, 2014), and how positioning is framed through enactment and storyline strategies (James, 
2014). Storyline refers to conventions and formats such as narratives with plot and characters, or a representation of a narrative (Harré, 2012).

Positioning theory distinguishes itself from a more role-based approach which is accused of being static and deterministic (Harré and Van Langenhove, 1999; Harré, 2012; Henriksen, 2008). A position is defined as 'a cluster of beliefs with respect to the rights and duties of the members of a group of people to act in certain ways' (Harré, 2012) and is seen as a more dynamic concept. However, the concepts of 'role' and 'long-term positions' come close to each other, as stated by Harré (2012:194).

Harré and Van Langenhove (1999) have proposed a model, the so-called 'positioning triangle', which expresses the core thinking of positioning theory and is conceived of as an analytic framework. At the three vertices of the model, we find the constituents Position, Storyline and Enactment. The three constituents of the model are considered mutually dependent. If one of them changes, all three change (Harré, 2012).

James (2010 and 2014) has contributed to the development of the original positioning theory framework by e.g. Harré and Van Langenhove (1999), proposing a strategic version of the model especially suited for organizational communication and public relations.

In James' strategic version of the triangle, she operates with a 'public relations position' which is: "a point of intentional representation discursively constructed for the purposes of achieving an intended outcome, and from where possibilities for action are established or in some cases denied, in terms of the local moral order/s wherein the public relations activity is taking place. Positioning comprises the actions taken to achieve the position” (2014:19).

Harré and Van Langenhove's positioning triangle provides a frame of understanding in this study, and James' strategic use of the positioning triangle is a source of inspiration for pointing to future actions.

\section{Results}

In the following, examples from the interviews will be presented and analyzed through the lenses of positioning theory.

In the context of a hospital ward with clear professional hierarchies, status is a powerful resource (see also Dutton et al., 2001). In the case of the hygiene coordinator, who is usually a nurse, the professional position of the nurse and the attached rights and duties seemingly set the basic framework for the practical communication of the hygiene-related tasks. However, the hygiene coordinator has to operate across the professional groups; and when addressing doctors, the expected distribution of rights and duties, and of practical tasks, is challenged.

Examples 1 and 2: Hygiene coordinator on reprimanding doctors:

- "It is especially difficult to reprimand doctors as they are seen as more powerful and competent than the nurses." 
- 'It can be difficult to tell a doctor 'you have to remember the apron.' It has to do with the distribution of power."

These quotes align with the basic insight from positioning theory that 'not everyone involved in a social episode has equal access to rights and duties to perform particular kinds of meaningful actions at that moment and with those people' (Harré, 2012:193). Had the action of reprimanding been accepted by the doctors, it would have caused positional changes. The examples show the role conflict experienced by the hygiene coordinator. She has to reprimand in order to perform her function, but she is doing so from a disadvantageous position.

Example 3: Hygiene coordinator on communicating hand hygiene to doctors:

Asking people to clean their hands is a directive action, which suggests asymmetry between the speaker and the recipient. As reported in the following example, the coordinator recipient-designed her communication by 1 . Accounting for her request, even before requesting, and 2. By deploying an account that is adjusted to the 'positivistic' thinking of doctors, and 3. By using politeness strategies ('would you', 'please').

- “...... it is very important to make them (the doctors) aware of these bacteria - they are more positivistic than we are - and that is why I put up little signs under the computers saying: 'You have this number of bacteria on your hands right now, so would you please clean your hands?’”

Examples 4 and 5: Hygiene coordinator on reprimanding colleagues (nursing staff):

This is another type of role conflict, namely between being the hygiene coordinator and a colleague. In order to perform her function, the coordinator needs to reprimand colleagues who do not obey the rules and procedures. The coordinator finds it extremely difficult to reprimand colleagues:

- "I have many concerns about being the hygiene coordinator. How can I reprimand? For example a colleague who has three rings on in the coffee room, and I know she will go to the hospital room in a while...it is difficult because they are colleagues and it will be personal."

The statement above regards symmetrical communication with colleagues. Also in this kind of situation, the action of reprimanding is difficult, due to the kind of directive action it is to reprimand. Again, by performing a reprimand, an asymmetry is suggested. The enactment implies a change of the involved positions, from symmetrical to asymmetrical.

The same problem, or role conflict, is expressed in the next extract. The hygiene coordinator does not want to act as a 'policeman' because it damages her relations with colleagues:

- “I don’t want the police function - nobody wants that because we are also colleagues.” 
This opinion is in remarkable accordance with the instructions from the infection control organization, as expressed at the course for new coordinators. It is seemingly a dilemma not wanting the so-called 'police function', and at the same time participating in a work life where follow-ups have to be performed in order to make procedures work. The hygiene coordinators do not want a position as 'reprimanders', and they do not have the kind of authority to support such a position.

\section{Examples 6 and 7: Hygiene coordinator on alternative communicative strategies:}

In this extract, the coordinator explains the necessity of regulating colleagues' behavior regarding hygiene measures. But instead of framing the necessary action as 'reprimanding', she talks about 'selling' the Danish Quality Model. In this context, 'selling' involves a persuasive action - and the message is not 'sold' until acceptance from the recipient is achieved. Issue selling is a dialogical endeavor, and involves dialogical processes:

- "We are not policemen, but I would say you are naive if you believe you can run around smiling at people and they just feel happy about your doings. The function is not like that. It is about selling the Danish Quality Model in the daily chores.”

The next extract reports an unsuccessful incident where the hygiene coordinators asked the nursing and cleaning personnel to clean the patient rooms every day, instead of every other day. The interviewee treats this incident as an unpleasant but instructive experience. Dictating is not an appropriate strategy - 'selling' paves the way for change.

- "We came in and told them to clean the patient rooms every day. They were about to kill us. We didn’t sell it - we dictated".

After this statement, the hygiene coordinator explains that the colleagues accepted the change after a dialogical process. Through persuasive efforts the hygiene coordinators "succeeded in linking the issue to the patient."

Example 8: Managing senior physician on the need for documentation:

The managing senior physician finds the area of hygiene insufficiently documented. He is skeptical about hygiene measures at the ward, and describes them as "often problematic" and not making sense:

- "To me hygiene is something where we have a good documentation that the hygiene measures we undertake do have an effect. And in my opinion, it is often problematic undertaking a lot of hygiene measures without having due documentation - from a clinical point of view, it does not always make sense. And we have had many discussions about it.”

This extract reflects the resistance towards hygiene measures which, according to the hygiene coordinators and the hygiene nurses, is common among the professional group of doctors. The senior physician emphasizes the unreasonableness of cumbersome procedures of hygiene in a very 
busy work environment. This opinion also sheds light on why the hygiene coordinators find it difficult to communicate with doctors about hygiene. How can they for instance accept a reprimand if they do not accept the basic premise that hygiene measures are effective?

Example 9: Managing senior nurse on the hygiene issue:

The managing senior nurse is engaged in hygiene issues, e.g. the hygiene nurses contact her for planning of hygiene measures and related activities. She is supportive of hygiene initiatives, but finds it stressful to pay much attention to them, due to the immense administrative workload of her function.

- "It is so exciting, this issue of hygiene. But this week we work with treatment of wounds, we work with social capital, the personnel has to fill out their report in the employee satisfaction survey. We are working with seven million other things, right? There is a constant competition for our attention.”

Example 10: Hygiene coordinator on the lack of support:

It is difficult to motivate local management to engage in and prioritize hygiene in a busy environment. Furthermore, the managing senior physician has a skeptical attitude towards hygiene measures, as we have seen. Therefore, the coordinator feels she is left on her own to deal with very complex tasks, not getting the necessary support.

- "It is difficult to engage management."

- "Nobody asks how the project is going ... nor does local management contact me asking how this or that is progressing, or ask staff themselves. It's just your project - it's delegated to Sonja, and then Sonja is in charge."

- "Ooohh, I am so alone.”

These conditions make the performance of the hygiene coordinator function difficult.

Findings from a meeting with the purpose of 'selling' new hygiene procedures

As we have seen, the interview data points to 'issue selling' as a communicative strategy for getting messages through and accepted. However, recorded data from meetings provides an insight into how the 'issue selling' is enacted in practice.

The meetings in question were 'morning meetings' for all groups of staff. Nevertheless, the participants were mainly nurses and aids. On these occasions, one of the hygiene coordinators presented new cleaning procedures, as preventive measures after the breakout of Clostridium difficile. As well the hygiene coordinator as the managing nurse knew they would be difficult meetings with significant resistance. So, the aim was to 'sell' new and cumbersome cleaning procedures. 
In order to persuade, the coordinator deployed a series of recipient-designed communicative resources, e.g. she laid the ground for dialogue and involvement of the recipients; she presented information using narrative structure in order to 'replay' (Goffman, 1974:504) work practices, using direct speech; she positioned herself and her messages by referring to the relevant audits held by the hygiene nurses and decisions to the department management; she was very focused on explaining and accounting for the changes in a very practice-oriented manner; and finally she used other vivid forms of communication such as metaphors and slogans (Kjærbeck and Petersen, 2013).

\section{Conclusions and practical implications}

These results point to the difficulties of gaining acceptance of hygiene-related changes, especially when crossing boundaries of the professional hierarchy. They highlight the hygiene coordinator's central problem of positioning in relation to the doctors' group.

A major challenge experienced by the hygiene coordinator is the skepticism, and sometimes overt resistance, from the group of physicians. In this case, the managing senior physician expresses his skepticism towards hygiene measures very clearly. Such an attitude from a person in his position will inevitably influence the opinion and behavior of the personnel, primarily the doctors, and it affects the collaboration between the different professional groups.

Another role conflict was reported in relation to colleagues, i.e. nurses and aids. The coordinator feels it is her duty to reprimand colleagues if they disregard the hygiene procedures. And by reprimanding from a symmetrical position, she challenges the collegial symmetry. It is interesting that the coordinators reproduce the wording that they 'don't want to act as policemen'. However, this understanding does not solve their dilemma. On the contrary, it seems necessary to perform follow-ups in order to improve hygiene at the ward.

As a consequence of her authority problem, the coordinator intentionally positions herself by 'borrowing' authority from the department management and from the infection control organization, referring to management's decisions, audits, and recommendations. She engages in narrative, direct communication depicting typical situations and behavior from the relevant work processes in order to explain why the change is necessary, thereby persuading skeptical personnel and 'selling' the issue. Dutton et al. define issue selling as "the process by which individuals affect others' attention to and understanding of the events, developments, and trends that have implication for organizational performance” (2001:716). The coordinator uses her local knowledge in order to affect her colleagues' attention and understanding. This local knowledge and communicative competence make the coordinator an efficient change agent in situations with nursing staff and aids.

However, an interesting question is what can be done in order to improve communication on hygiene in the ward. The findings suggest an authority problem and call for a strategic positioning of the hygiene coordinator.

The expressed urgency for additional documentation in relation to hygiene measures at the ward is obviously an important area to pay attention to. Seen from the physicians' point of view, and in the 
light of change communication, understanding the reason for and purpose of the changes is crucial for staff's motivation, and consequently for the implementation of change. Paying more attention to documentation would, furthermore, empower the hygiene coordinator in her position.

A study by Dutton et al. shows that "connecting an issue to valued goals is associated with effective issue selling” (2001:723). In the hospital context, the most valued goal is without doubt linked to the patient: Saving lives and improving patients' quality of life. Hygiene must be framed as a lifesaving endeavor, in accordance with reality, in order to be taken seriously. This change in approach needs be communicated from top management, from the hygiene committee (see Figure 1), as a core message or storyline. This storyline strategy would pave the way for changes in practical enactment and positioning (see also James 2010, 2014).

Furthermore, the study points to the importance of strengthening the communication between the departmental management and the hygiene coordinator. There is a need for intensified coordination and planning of hygiene-related tasks and strategies, and a need for support of the hygiene coordinator in practical actions, e.g. by opening and closing important meetings.

Finally, the necessity of following up and being able to perform reprimanding actions in motivating ways would suggest that more training and a strengthening of the coordinator's dialogic skills are needed.

\section{Research limitations and future research}

The research presented is based on a case study in a specific hospital ward, and in a Danish hospital context, and therefore the results may not be generalizable (Flyvbjerg, 2006). However, additional interviews with hygiene coordinators from five different departments/hospitals confirm the findings of the presented study (Weinrich et al., 2014). And the results have been presented and discussed with hospital staff on numerous occasions, and they clearly express their recognition of the presented dilemmas and challenges. Future research could extend the study of the relevant professional groups across other wards and other hospitals, in order to test the applicability of the findings. And the qualitative, explorative methods applied could even be supplemented with a survey in a triangulated research design. The findings of the study call for more research on how organizational culture and collaboration across professional boundaries can facilitate and improve hygiene at ward level, and how initiatives at ward level can be integrated with top management strategies for hygiene.

\section{References}

Anderson, R., Baxter, L.A. and Cissna (Eds.) (2004), Dialogue. Theorizing Difference in Communication Studies, SAGE Publications, Thousand Oaks, London, New Delhi.

Balogun, J. (2003), "From blaming the middle to harnessing its potential: creating change intermediaries”, British Journal of Management, 14, pp. 69-83. 
Bamberg, M. (2008), "Selves and identities in the making: The study of microgenetic processes in interactive practices”, in Müller, U., Carpendale, J., Budwig, J. \& Sokol, B. (Eds.), Social life and social knowledge, Erlbaum, Mahwah, NJ, pp. 205-224.

Braut, G.S. and Holt, J. (2011), "Meticillin-resistant Straphylococcus aureaus infection - the infectious stigma of our time?” Journal of Hospital Infection, 77, 2, pp. 148-152.

Dahllöf, S. (2014), “Three deaths of hospital bacteria spread by pigs”, Investigative Reporting Denmark, available at: http://www.ir-d.dk/2014/05/three-deaths-of-hospital-bacteria-spread-bypigs/ (accessed 8 February 2016).

Davies, B. and Harré, R. (1990), "Positioning: The Discursive Production of Selves”, Journal for the Theory of Social Behaviour, 20, 1, pp. 43-63.

Day, D. and Kjaerbeck, S. (2013), “'Positioning' in the conversation analytic approach”, Narrative Inquiry, 23, 1, pp. 16-39.

Deppermann, A. (2013), “How to get a grip on identities-in-interaction. Does 'Positioning' offer more than 'Membership Categorization'? Evidence from a mock story”, Narrative Inquiry, 23, 1, pp. 62-88.

Dutton, J.E., Ashford, S.J. \& O’Neill, L.K.A. (2001), “Moves that matter: Issue selling and organizational change”, Academy of Management Journal, 44, 4, pp. 716-736.

Feigenbaum, E. (2012), “Organizational Structure of Hospitals”, available at: http://smallbusiness.chron.com/organizational-structure-hospitals-3811.html (accessed 10 January 2016).

Fenton, C. and Langley, A. (2011), “Strategy as Practice and the Narrative Turn”, Organization Studies, 32, 9, pp. 1171-1196.

Floyd, S.W. and Wooldridge, B. (1997), “Middle Management’s Strategic Influence and Organizational Performance”, Journal of Management Studies, 34, 3, pp. 465-485.

Flyvbjerg, B. (2006) “Five Misunderstandings About Case-Study Research”, Qualitative Inquiry, 12, 2, pp. 219-245.

Gergen, K.J., Gergen, M.M. \& Barrett, F.J. (2004), “Dialogue: Life and death of the organization”, in Grant, D., Hardy, C., Owick, C., Phillips, N. \& Putnam, L.L. (Eds.), The SAGE Handbook of Organizational Discourse, SAGE Publications, London, pp. 39-60.

Glickman, S.W., Baggett, K.A., Krubert, C.G., Peterson, E.D. \& Schulman, K.A. (2007), "Promoting quality: the health-care organization from a management perspective", International Journal for Quality in Health Care Promoting Quality: The Health-Care Organization From a Management Perspective, 19, 6, pp. 341-348. 
Goffman, E. (1974), Frame analysis: An essay on the organization of experience, Harvard University Press, Cambridge, MA.

Gubrium, J.F. and Holstein, J.A. (1995), The Active Interview, Sage, Thousand Oaks, CA.

Gubrium, J.F. and Holstein, J.A. (Eds.) (2002), Handbook of Interview Research: Context and Method, Sage, Thousand Oaks, CA.

Harré, R. (2012), “Positioning Theory: Moral Dimensions of Social-Cultural Psychology”, in Valsiner, J. (Ed.), The Oxford Handbook of Culture and Psychology, Oxford University Press, Oxford, pp. 191-206.

Harré, R. and Van Langenhove, L. (1999), Positioning Theory: Moral Contexts of Intentional Action, Blackwell Publishers, Oxford.

Hazel, S. (2015), “The paradox from within: research participants doing-being-observed”, available at: http://qrj.sagepub.com/content/early/2015/08/26/1468794115596216.abstract (accessed 8 May 2016).

Hewison, A. (2002), "Managerial values and rationality in the UK national health service”, Public Management Review, 4, 4, pp. 549-579.

Hildebrandt, S. (2014), “Ud med dokumentationstyranniet og ind med tillid”, available at: http://www.lederweb.dk/strategi/organisationskultur/artikel/110797/hildebrandt-new-publicmanagement-har-spillet-fallit (accessed 8 May 2016).

Hildebrandt, S. and Brandis, S. (2010), Forandringsledelse, Børsens Forlag, Copenhagen.

James, M. (2010), “A Provisional Conceptual Framework for Intentional Positioning in Public Relations”, Journal of Public relations Research, 23, 1, pp. 93-118.

James, M. (2014), Positioning Theory and Strategic Communications: A New Approach to Public Relations Research and Practice, Routledge New directions in Public Relations \& Communication Research, London.

Kelliher, C. and Parry, E. (2015), “Change in healthcare: the impact on NHS managers”, Journal of Organizational Change Management, 28, 4, pp. 591-602.

Kolmos, H.J. (2012), “Antibiotika til husdyr: billigt for landbruget, dyrt for sundhedsvæsenet”, available at: http://videnskab.dk/miljo-naturvidenskab/antibiotika-til-husdyr-billigt-landbruget-dyrtsundhedsvaesenet (accessed 5 January 2016).

Kotter, J.P. (1995), “Leading Change: Why Transformation Efforts Fail”, Harvard Business Review, available at: http://www.gsbcolorado.org/uploads/general/PreSessionReadingLeadingChange-John_Kotter.pdf (accessed 17 April 2016). 
Kvale, S. (2008), Doing Interviews - Qualitative Research Kit, SAGE Publications, London.

Kjærbeck, S. (2014), “Kvalitative interviews: Om at få indblik i målgruppers holdninger, erfaringer og adfærd”, in Petersen, H. (Ed.), Organisationskommunikation: Teori og cases om tekst og tale, Samfundslitteratur, Copenhagen, pp. 155-178.

Kjærbeck, S. and Petersen, H. (2013), “Change Communication on hygiene - research and findings”, presentation for staff, 8 January 2013, Odense Universitetshospital, Odense, Denmark.

Kjærbeck, S. and Petersen, H. (2014), “Kommunikation er en forudsætning for at forbedre hygiejnen på hospitaler”, Ugeskrift for leger, 8, pp. 771-773.

Larkin, T.J. and Larkin, S. (1994), Communicating Change. Winning Employee Support for the New Business Goals, McGraw-Hill, New York.

Lucius-Hoene, G. and Deppermann, A. (2000), “Narrative identity empiricized: A dialogical and positioning approach to autobiographical research interviews”, Narrative Inquiry, 10, 1, pp. 199222.

Moghaddam, F.M. and Harré, R. (2003), The Self and Others: Positioning Individuals and Groups in Personal, Political, and Cultural Contexts, Praeger, Westport, CT.

Omari, M. and Paull, M. (2015), "Public sector work intensification and negative behaviors", Journal of Organizational Change Management, 28, 4, pp. 603-613.

Petersen, H. (2000), Forandringskommunikation, Samfundslitteratur, Copenhagen.

Rogers, E.M. (1971/2003, 5 ${ }^{\text {th }}$ ed.), Diffusion of Innovations, Free Press, New York.

Sultz, H.A. and Young, K.M. (2010, $7^{\text {th }}$ ed.), Health Care USA: Understanding its Organization and Delivery, Jones and Bartlett Learning, Burlington, MA.

Tsoukas, H. and Chia, R. (2002), “On Organizational Becoming: Rethinking Organizational Change”, available at: http://dx.doi.org/10.1287/orsc.13.5.567.7810 (accessed 7 February 2016).

Weick, K.E. and Quinn, R.E. (1999), “Organizational Change and Development”, Annual Review of Psychology, 50, pp. 361-386.

Weinreich, K.C., Waidtsløw, K. \& Hansen, R.K. (2014), Hygiejnekoordinator som forandringsagent, unpublished M.A. thesis in Communication Studies, Roskilde University, Roskilde, supervisor: Susanne Kjærbeck.

Zorn, T., Christensen, L.T. \& Cheney, G. (1999), Do We Really Want Constant Change? BerrettKoehler, San Francisco, CA.

Zorn, T.E., Page, D.J. \& Cheney, G. (2000), "Nuts about Change: Multiple Perspectives on Change-Oriented Communication in a Public Sector Organization”, Management Communication Quarterly, 13, 4, pp. 515-565. 
